\title{
"Determining the level of bank connectivity for combating money laundering, terrorist financing and proliferation of weapons of mass destruction"
}

\author{
Nataliya Vnukova iD http://orcid.org/0000-0002-1354-4838 \\ R http://www.researcherid.com/rid/T-9097-2018 \\ Sergii Kavun (D https://orcid.org/0000-0003-4164-151X \\ R http://www.researcherid.com/rid/A-1847-2012 \\ AUTHORS \\ Oleh Kolodiziev iD http://orcid.org/0000-0002-6715-2901 \\ R http://www.researcherid.com/rid/C-6094-2018 \\ Svitlana Achkasova iD https://orcid.org/0000-0001-7233-0189 \\ R http://www.researcherid.com/rid/L-1576-2017 \\ Daria Hontar (D) http://orcid.org/0000-0001-5416-9328 \\ R http://www.researcherid.com/rid/C-9917-2017
}

ARTICLE INFO

Nataliya Vnukova, Sergii Kavun, Oleh Kolodiziev, Svitlana Achkasova and Daria

ARTICLE INFO
Hontar (2019). Determining the level of bank connectivity for combating money laundering, terrorist financing and proliferation of weapons of mass destruction. Banks and Bank Systems, 14(4), 42-54. doi:10.21511/bbs.14(4).2019.05

DOI http://dx.doi.org/10.21511/bbs.14(4).2019.05

\section{RELEASED ON}

Friday, 29 November 2019

RECEIVED ON

Saturday, 05 October 2019

ACCEPTED ON

Monday, 11 November 2019

\section{(c)) EY}

LICENSE

This work is licensed under a Creative Commons Attribution 4.0 International License

\begin{tabular}{ll} 
JOURNAL & "Banks and Bank Systems" \\
\hline ISSN PRINT & $1816-7403$ \\
\hline ISSN ONLINE & $1991-7074$ \\
\hline PUBLISHER & LLC "Consulting Publishing Company "Business Perspectives" \\
\hline FOUNDER & LLC "Consulting Publishing Company "Business Perspectives"
\end{tabular}

NUMBER OF REFERENCES

38
NUMBER OF FIGURES

5
琵

NUMBER OF TABLES

4

(C) The author(s) 2023. This publication is an open access article. 


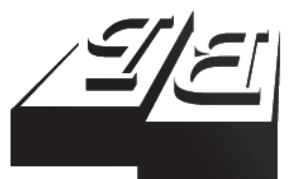

BUSINESS PERSPECTIVES

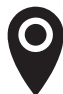

LLC "CPC "Business Perspectives" Hryhorii Skovoroda lane, 10, Sumy, 40022, Ukraine

www.businessperspectives.org

Received on: $5^{\text {th }}$ of October, 2019 Accepted on: $11^{\text {th }}$ of November, 2019

(C) Nataliya M. Vnukova, Sergii V. Kavun, Oleh M. Kolodiziev, Svitlana A. Achkasova, Daria D. Hontar, 2019

Nataliya M. Vnukova, Doctor of Economics, Professor, Head of the Department of Financial Services Management, Simon Kuznets Kharkiy National University of Economics, Ukraine.

Sergii V. Kavun, Doctor of Economics, Professor, Rector of Kharkiv University of Technology “STEP”, Ukraine.

Oleh M. Kolodiziev, Doctor of Economics, Professor, Head of the Department of Banking, Simon Kuznets Kharkiv National University of Economics, Ukraine.

Svitlana A. Achkasova, Ph.D. in Economics, Associate Professor of the Department of Financial Services Management, Simon Kuznets Kharkiv National University of Economics, Ukraine.

Daria D. Hontar, Ph.D. in Economics, Lecturer of the Department of Banking, Simon Kuznets Kharkiv National University of Economics, Ukraine.

\section{(c) (i)}

This is an Open Access article, distributed under the terms of the Creative Commons Attribution 4.0 International license, which permits unrestricted re-use, distribution, and reproduction in any medium, provided the original work is properly cited.
Nataliya M. Vnukova (Ukraine), Sergii V. Kavun (Ukraine), Oleh M. Kolodiziev (Ukraine), Svitlana A. Achkasova (Ukraine), Daria D. Hontar (Ukraine)

\section{DETERMINING THE LEVEL OF BANK CONNECTIVITY FOR COMBATING MONEY LAUNDERING, TERRORIST FINANCING AND PROLIFERATION OF WEAPONS OF MASS DESTRUCTION}

\begin{abstract}
The study aims at developing an approach to determining the bank connectivity level. This will contribute to implementing a risk-oriented approach to counteracting money laundering, terrorist financing and the proliferation of mass destruction weapons. The article proposes to assess the degree of bank connectivity and determine the impact of these circumstances on money laundering risk using banks from foreign banking groups, whose capital share in the Ukrainian banking system amounts to more than 40 percent. Using the resulting correlation dependencies, two-dimensional binary matrices were constructed, which became the basis for creating graphs of links between banks. The institutions under study are found to be predominantly connected in terms of their sets (varieties), since the average proportion of banks with close direct links is over half, and the non-connectivity coefficient for them is about $40 \%$. Each surveyed bank, on average, has direct links with eight other banks and inverse links with four other banks. Considering banks as tops of the graph, one can assume that there is a hidden relationship between some banks. This approach allows calculating all existing relationships between banks to assess risk. Transforming the graph from non-oriented to oriented made it possible to identify and clearly demonstrate possible directions of links between the investigated financial institutions, which should be further verified to determine the risk of money laundering, terrorist financing, etc.
\end{abstract}

\section{Keywords}

bank, graph theory, connectivity, FATF international standards, risk-oriented approach, counteracting money laundering

JEL Classification C53, G17, G21

\section{INTRODUCTION}

Money laundering (ML), terrorist financing (TF), and financing the proliferation of weapons of mass destruction (WMD) are significant global dangers affecting the financial system. To counteract them, FATF International Standards (2012) (FATF, 2012; Achkasova, 2019) were developed. To implement them, different approaches and techniques are developed to assess and manage risks in the financial monitoring system, apply a risk-oriented approach to counteracting ML, TF and WMD, and evaluate its effectiveness.

Adopted in November 2019, in the first reading, the draft amendments to the Law of Ukraine "On Preventing and Counteracting to Legalization (Laundering) of the Proceeds of Crime, Terrorist Financing and Financing Proliferation of Weapons of Mass 
Destruction" (The Verkhovna Rada of Ukraine, 2019) change the paradigm of developing a financial monitoring system based on risk-oriented approach. This is the case of the outcome of the risk assessment by the primary financial monitoring entity, based on the analysis of a set of defined criteria, which may indicate a high likelihood of using the primary financial monitoring entity to legalize (launder) proceeds from crime, terrorist financing and/or financing the proliferation of mass destruction weapons.

According to this draft law, it is risk management, that is, taking measures by financial institutions to create and ensure the functioning of the risk management system, which includes, in particular, the definition (detection), assessment/revaluation (measurement), monitoring, control of risks to minimize them, that changes the financial monitoring system priorities. Introducing a risk-oriented approach that aims at identifying (detecting), assessing (re-evaluating) and understanding the risks of legalizing (laundering) proceeds from crime, terrorist financing or the proliferation of mass destruction weapons, and taking appropriate management measures in the way and to the extent that ensure the effective minimization of such risks depending on their level (The Verkhovna Rada of Ukraine, 2019), should further be based on methodological guidelines for determination, assessment/revaluation (measurement), and control of risks.

Financial relations, in particular, banking activities, need constant monitoring, taking into account the intensification of both global and internal risks. The national risk assessment in the field of ML, TF and WMD (SFMS, 2016) in Ukraine, distinguishes a broad list, which requires finding new approaches to developing methods of control over potential risks arising in the primary financial monitoring system, in particular, in banks (SFMS, 2016; Hlibko, Vnukova, Hontar, Anisimova, \& Liubchych, 2019).

Therefore, it is important to improve the risk management process in the area to further implement FATF international standards, in particular, the guidelines for identifying the networks that are proposed to identify through the connectivity of financial institutions, such as banks.

A good example of bank connectivity is that they have joint clients who receive credit facilities or conduct cash transactions. In this case, the connected banks have a common source of credit repayment and thus bear common economic risk or may create networks to transfer funds. The lack of the necessary methodological framework for assessing bank connectivity to counteract fund legalization significantly reduces the ability to assess the level of these risks efficiently.

The quality of the financial monitoring risk assessment system adopted by a particular bank (Ministry of Finance of Ukraine, 2016) influences its ability to withstand negative changes in the economy and financial sphere. By providing financial services to one customer, the bank accepts the risks of all related and/or connected parties equal to the amount of the financial service provided (Omelchenko, Dorokhov, Kolodiziev, \& Dorokhova, 2018). This leads to the need to treat all these individuals as one potential network client, which reinforces the need for new analysis and evaluation tools, and to conduct an economic analysis of the financial activities of all related and connected parties.

\section{LITERATURE REVIEW}

Several authors investigate system connectivity in Ukraine (Avramchykova, 2012; Poliakova \& Simarova, 2014; Chepyk, 2013). Thus, Avramchykova (2012) assessed the quality of economic area in resource-oriented regions and developed relevant tools taking into account the density, uniformity of production location and connectivity of economic entities. Poliakova and Simarova (2014) consider connectivity as an attribute of spatial development, which is a characteristic of the management object in the course of economic policy. Chepyk (2013) proposes to estimate the unevenness of interregional development in different economy areas using the inequality index and to investigate the influence of various factors on the size of these coefficients. Vnukova, 
Hontar, and Vorotyntsev (2018) used graph theory to address the issues of determining the degree of financial institutions' connectivity, for example, credit unions and financial companies.

The legislation of Ukraine, in particular, the Tax Code of Ukraine (The Verkhovna Rada of Ukraine, 2010), the Resolution of the Board of the National Bank of Ukraine dated August 28, 2001 No. 368 "On approval of the Instruction on the procedure for regulating the activity of banks in Ukraine" (National Bank of Ukraine, 2001), Regulation (standard) of accounting 23 Related Party Disclosures (Ministry of Finance of Ukraine, 2012b), International Accounting Standard (IAS) 24 Related Party Disclosures (Ministry of Finance of Ukraine, 2012a), addresses the issue of related parties. The Regulation on determining the size of credit risk by active banking transactions by banks of Ukraine (National Bank of Ukraine, 2016) stipulates that related parties are considered legal entities that belong to one group (parent and subsidiaries), have joint owners of substantial shareholding (or are owners of substantial mutual shareholding), investors, final beneficiaries, use financial services for joint activities and have a common source of funding.

Exclusivity, economic dependence, shared infrastructure, lack of transparency, purpose of use of funds, documentation, operating standards, debt and credit, internal controls, interest rates, commissions and prices, collateral and guarantees are the key features of determining connectivity.

However, there is almost no research on taking into account the financial institution connectivity in assessing the financial monitoring risk. The criteria for determining the connection of persons in national legislation are not specified. Vnulova at al. (2018) tried to estimate the connectivity level using some financial Ukrainian institutions as an example.

\section{RESEARCH PURPOSE}

The purpose of the study is to develop an approach to determining the level of bank connectivity, the use of which will contribute to the implementation of a risk-oriented approach to counteracting money laundering, terrorist financing and the proliferation of weapons of mass destruction.

\section{RESEARCH METHODS}

Graph theory (Cristofides, 1978; Kavun \& Vorotyntsev, 2016; Kavun, Mykhalchuk, Kalashnykov, \& Zyma, 2012; Trybid, Kavun, \& Goykhman, 2014) can be used to investigate the bank connectivity level. The theory can be applied in all industries where there are elements and relationships between the banks (Rose \& Kolari, 1995). Graph is one of the most common and popular mathematical models in many science and technology fields. The image in the form of a set of points on a plane and the lines drawn between some of them have become a convenient and visual form to reflect particular processes and phenomena.

Graph theory emerged in 1736 from the works of Leonard Euler (1707-1783), the Swiss mathematician (Graph Theory, n. d.). In a set theory, a graph is any representation of a set in itself. The set element, which creates a graph, is called a vertex. Some scientists also call them points. An oriented pair $(X i, X j)$ of vertices $X i$ and $X j$ is called an arc; a path is a series of coupled arcs that allow one to move from one vertex to another; a contour is a path whose initial vertex coincides with an end one; a self-loop is an arc, whose beginning and end coincide; the length of a path or contour is the number of a path's or contour's arcs; if two graph vertices are connected by an arc beginning in either of them, then there is an edge between these vertices, so the concept of an edge is equivalent to the concept of an "undirected" graph.

A chain is a sequence of coupled edges, that is, a sequence of arcs that are coupled without taking into account their orientation. Any path is obviously a chain, but a chain is not always a path. By type, graphs are divided into oriented and non-oriented. An oriented graph (or digraph) is a pair of sets $\mathrm{V}$ and $\mathrm{E}$, where $\mathrm{V}$ is not an empty finite set, and $\mathrm{E}$ is a set of ordered pairs of the set $\mathrm{V}$ elements (Kofman, 1968). In this case, the elements of the set $\mathrm{V}$ are called vertices (or nodes), and those of the set $\mathrm{E}$ are arcs (or oriented edges). If a pair of vertices $a$ and $b$ are an arc, then it is denoted as $(a, b)$. The vertex $a$ is called the initial vertex and the vertex $b$ is the terminal vertex. The $\operatorname{arc}(a, a)$ is called a self-loop. 


\section{RESULTS}

It is suggested to assess the degree of bank connectivity and define its impact on money laundering and terrorist financing risks in several stages.

\subsection{Search of the research information base}

This stage involves selecting and forming a set of banks for the study.

The Committee on Banking Supervision and Regulation, Payment System Monitoring (Oversight) of the National Bank of Ukraine has determined criteria to classify banks into groups for the year 2019. According to its decision as of February 28, 2019 No. 70, the following groups are provided (National Bank of Ukraine, 2019a): publicly owned banks are banks in which the state directly or indirectly holds more than $75 \%$ of the bank's authorized capital; banks of foreign banking groups are banks whose majority stakes are owned by foreign banks or foreign financial and banking groups; private equity banks are banks where one or more private investors, directly and/or indirectly owning at least $50 \%$ of the bank's authorized capital, are among the ultimate owners of substantial shareholding.

The National Bank of Ukraine will use this distribution in analyzing the Ukrainian banking system activity. Although a significant portion is owned by publicly owned banks (44.9\%), their number (5) is insufficient to investigate the relationships of financial institutions and identify specific networks. Therefore, the connectivity level is proposed to be studied using foreign banks as an example. This is due to the fact that according to the National Bank of Ukraine, over the last five years, the share of foreign capital has been constantly changing in the Ukrainian banking system, and it was $41.02 \%$ as of March 1, 2019 (National Bank of Ukraine, n. d.).

It should be noted that foreign-owned banks proved to be more resilient during the crisis period as evidenced by the outperformance of the fall in the number of banks with private capital compared to the fall in the number of active foreign-owned banks.
The choice of key indicators for evaluating the bank's activity was based on the views of many authors, such as Gerasimovich, Alekseenko, and Parasiy-Verhunenko (2004), Prymostka (1999), Buriak (2010), Batrakova (2005), Moroz, Savluk, and Pukhovkina (2000), Khrystenko (2012), Kohdenko (2012), and Fedotova (2010) (see Table 1), who suggested that profitability ratios are the main indicators of the bank's activity.

The purpose of any business activity, including banking, is to get a certain economic effect, which reflects itself in the bank's profitability ratios and influences the decision of investors to invest in a particular bank. Table 1 gives indicators offered by Ukrainian and international scientists that characterize bank profitability.

As Table 1 shows, in estimating the bank profitability, the usage of certain indicators by the authors is from 2 to 11 .

For further calculations of the bank connectivity level, it is proposed to use the indicators, which were most often found in the writings of Ukrainian and foreign authors: return on equity, return on assets (earning power), net interest margin, net spread, and return on assets. Meanwhile, the return on assets ratio, which according to Table 1 has the highest frequency of use, is chosen for analysis.

The calculations used the monthly performance ratios of 21 banks during 2018 on the example of all banks of foreign banking groups (National Bank of Ukraine, 2019b) (Among them are Raiffeisen Bank Aval, Alfa-Bank, Ukrsibbank, and OTP Bank).

As of March 1, 2019, the total assets of the 21 banks belonging to the institutions of foreign banking groups and forming the data base for the research amounted to over UAH 1,600 billion, the net assets of these banks were $29.9 \%$ of the total net assets of Ukrainian banks, including UAH 402 billion, the liabilities of this group of banks amounted to UAH 334 billion: 21 banks had 1.7 thousand subdivisions (National Bank of Ukraine, 2019b). 
Table 1. Bank profitability ratios

\begin{tabular}{|c|c|c|c|c|c|c|c|c|c|c|c|}
\hline \multirow[b]{2}{*}{ Bank profitability indicator } & \multicolumn{11}{|c|}{ Source } \\
\hline & 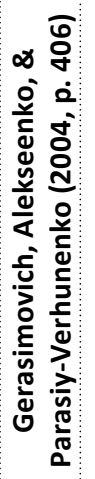 & 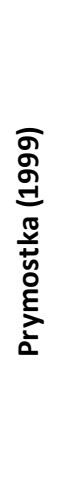 & 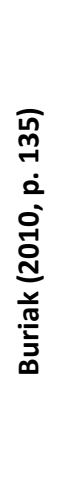 & 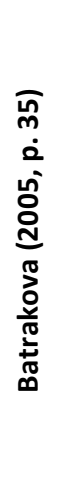 & 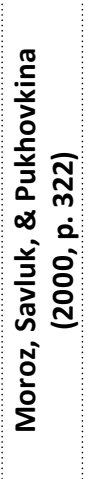 & 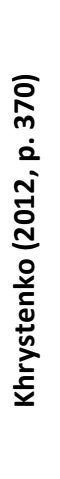 & 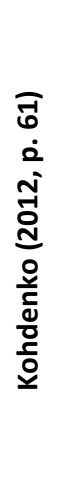 & 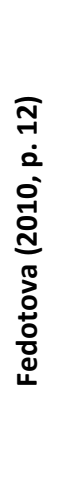 & 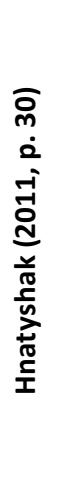 & 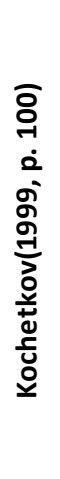 & 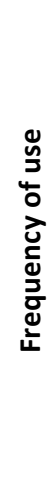 \\
\hline Return on assets (earning power) & + & + & + & + & + & + & + & + & & + & 9 \\
\hline Return (profitability) on equity & + & + & + & + & + & + & + & + & + & & 9 \\
\hline Net interest margin & + & + & + & + & + & + & + & & & & 7 \\
\hline Net spread & + & + & + & + & & + & & + & & & 6 \\
\hline Return on assets & & & & & + & & & & & + & 2 \\
\hline Net income per share & & + & & & & + & & & & & 2 \\
\hline Net return on equity ratio & & & & & & & + & & + & & 2 \\
\hline Cost-effective profitability & + & & + & & & & & & & & 2 \\
\hline Before-tax income & & + & & & + & & & & & & 2 \\
\hline The dead point of bank profitability & + & & & + & & & & & & & 2 \\
\hline Level of other operating income & + & & & & & & & & & & 1 \\
\hline Return on costs & + & & & & & & & & & & 1 \\
\hline Total profitability & + & & & & & & & & & & 1 \\
\hline Cost recovery by means of earning & + & & & & & & & & & & 1 \\
\hline Return on earning assets & + & & & & & & & & & & 1 \\
\hline Net non-interest margin & & + & & & & & & & & & 1 \\
\hline The ratio of non-interest income to average total assets & & + & & & & & & & & & 1 \\
\hline Frequency of use & 11 & 8 & 5 & 5 & 5 & 5 & 4 & 3 & 2 & 2 & 50 \\
\hline
\end{tabular}

\subsection{Determining the relationship density between financial institutions}

The study used the strength of relationship concept. It is based on calculating correlation coefficients and is defined as the connectivity ratio in the constructed connectivity graph of financial institutions, in particular banks.

The closeness of financial institutions is defined by calculating Pearson correlation coefficients $\left(r_{i j}\right)$ using the bank profitability ratios (Chaddock scale, n. d.).

After calculating the correlation coefficients, a matrix of their values was built using the one-to-one principle.
Also, given the matrix properties, it is determined that the secondary diagonal of the matrix always contains a value of " 1 ", because each financial institution relies on itself. The correlation matrix is symmetric as to the minor diagonal, according to which the correlation coefficient is always 1 , because the correlation is calculated for all banks. In this way, such a matrix can be considered as diagonal.

\subsection{Selection of closely related banks based on a two-dimensional binary matrix built}

At this stage, closely related banks (according to Chaddock scale), for which the correlation coefficient module exceeds 0.7 , and weakly correlated banks, for which the correlation coefficient module is less than 0.7 , are distinguished for further investigation. 
The proposed approach to determining bank connectivity allows considering both direct and inverse relationships between banks based on a dedicated bipartite graph (divided into two subsets).

Table 2 presents the results of the calculations of indicators characterizing the financial institutions' connectivity across multiple banks with direct and inverse relationships.

Indicators for assessing the connectivity level of financial institutions (banks) from Table 2 are calculated as follows:

$X_{1}=\frac{1}{j} \sum_{i=1}^{n}\left\langle p_{i j}>0.7\right\rangle, p_{i j} \in\{B\}, i, j=\underline{1.21}$,

where $n$ is the number of financial institutions, in this case $n=21 ; p_{i j}$ is an element of the correlation density matrix.

$$
\begin{aligned}
& X_{2}=\frac{1}{j} \sum_{i=1}^{n}\left\langle p_{i j} \leq 0.7\right\rangle, p_{i j} \in\left\{B_{i j}\right\}, i, j=\underline{1.21}, \\
& X_{3}=X_{1}-X_{2}, \\
& X_{4}=\frac{1}{j} \sum_{j=1}^{n} \frac{X_{1 j}}{X_{1 j}+X_{2 j}}(\%), \\
& X_{1 j} \in\left\{X_{1}\right\}, X_{2 j} \in\left\{X_{2}\right\}, i, j=\underline{1.21}, \\
& X_{5}=\frac{1}{j} \sum_{j=1}^{n} \frac{X_{2 j}}{X_{1 j}+X_{2 j}}(\%), \\
& X_{1 j} \in\left\{X_{1}\right\}, X_{2 j} \in\left\{X_{2}\right\}, i, j=\underline{1.21},
\end{aligned}
$$

\begin{tabular}{|c|c|c|c|c|c|c|c|}
\hline $\begin{array}{l}\text { A set of financial } \\
\text { institutions }\end{array}$ & 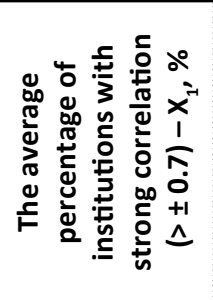 & 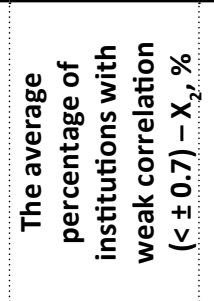 & 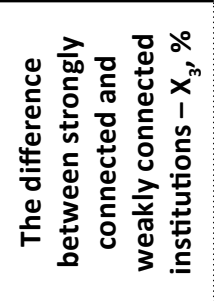 & 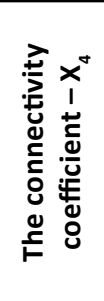 & 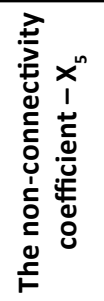 & 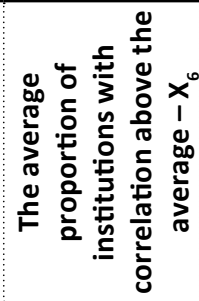 & 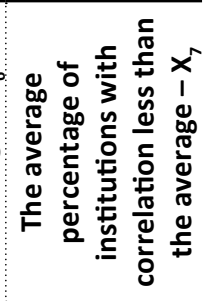 \\
\hline $\begin{array}{l}\text { Banks of foreign } \\
\text { banking groups with } \\
\text { direct links }\end{array}$ & 41.50 & 58.50 & -17.00 & 0.41 & 0.59 & 61.90 & 38.10 \\
\hline $\begin{array}{l}\text { Banks of foreign } \\
\text { banking groups with } \\
\text { inverse links }\end{array}$ & 23.26 & 76.64 & -53.29 & 0.23 & 0.77 & 14.29 & 85.71 \\
\hline
\end{tabular}

Table 2. Connectivity indicators across multiple financial institutions (banks)
$X_{6}=\sum_{j=1}^{m} \sum_{i=1}^{n}\left\langle p_{i j}>\frac{1}{n \times m} \sum_{i=1}^{n} \sum_{j=1}^{m} p_{i j}\right\rangle$,

$$
X_{7}=\frac{X_{62}}{X_{61}+X_{62}}, p_{i j} \in\{B\}, i, j=\underline{1.21} .
$$

$X_{1}, X_{2}, X_{3}, X_{4}, X_{5}, X_{6}, X_{7}$ are the connectivity indicators for the multiple financial institutions (banks) listed in Table 2.

Table 2 concludes that the financial institutions investigated are mostly connected in the volume of their sets, since the average proportion of banks with direct relationships with high density is more than $61 \%$ and the non-connectivity coefficient for them is about $38 \%$.

For banks with inverse correlation, this indicator is much smaller, i.e., $14.29 \%$. That is, in the studied banks of foreign banking groups, direct links prevail.

\subsection{Calculation of bank connectivity weights}

At this stage, ranks for each financial institution that characterize links with a correlation coefficient module value greater than 0.7 are calculated, that is, for highly connected financial institutions.

The greater the amount of relationships (based on a binary matrix built), the more dependent financial institutions are. Rank calculation makes it possible to determine the value of this sum relative to other values in the set. 
To determine the financial institution's rank, the RANK function in Microsoft Excel ${ }^{\mathrm{TM}}$ is used.

\subsection{Confirming the hypothesis of correlation between connected and non-connected financial institutions}

At this stage, using the existing graph theory algorithms (Cristofides, 1978), the number of links of each financial institution is analyzed. Also, the groups of financial institutions that are linked are distinguished, and a conclusion is made to confirm the hypothesis of financial institutions' connectivity.

To determine the rank of banks, the RANK function is used in Microsoft Excel ${ }^{\mathrm{TM}}$. Table 3 gives the number of bank relationships.

Table 3. Ranks of bank connectivity ratios and number of bank direct and inverse links

\begin{tabular}{|c|c|c|c|c|}
\hline \multirow{2}{*}{$\begin{array}{l}\text { Bank code } \\
\text { term }\end{array}$} & \multicolumn{2}{|c|}{$\begin{array}{l}\text { In the set with direct } \\
\text { links }\end{array}$} & \multicolumn{2}{|c|}{$\begin{array}{c}\text { In the set inverse } \\
\text { links }\end{array}$} \\
\hline & $\begin{array}{l}\text { Bank } \\
\text { rank }\end{array}$ & $\begin{array}{c}\text { The } \\
\text { number of } \\
\text { bank links }\end{array}$ & $\begin{array}{l}\text { Bank } \\
\text { rank }\end{array}$ & $\begin{array}{c}\text { The } \\
\text { number of } \\
\text { bank links }\end{array}$ \\
\hline 1 & 2 & 3 & 4 & 5 \\
\hline 1 & 6 & 12 & 12 & 3 \\
\hline 2 & 10 & 12 & 8 & 3 \\
\hline 3 & 15 & 2 & 19 & 13 \\
\hline 4 & 3 & 12 & 15 & 3 \\
\hline 5 & 18 & 0 & 1 & 0 \\
\hline 6 & 16 & 2 & 20 & 13 \\
\hline 7 & 2 & 12 & 11 & 3 \\
\hline 8 & 5 & 12 & 9 & 3 \\
\hline 9 & 7 & 12 & 14 & 3 \\
\hline 10 & 4 & 12 & 10 & 3 \\
\hline 11 & 1 & 12 & 16 & 3 \\
\hline 12 & 9 & 12 & 7 & 3 \\
\hline 13 & 13 & 12 & 18 & 4 \\
\hline 14 & 18 & 0 & 5 & 2 \\
\hline 15 & 17 & 1 & 4 & 1 \\
\hline 16 & 11 & 12 & 17 & 3 \\
\hline 17 & 14 & 2 & 21 & 13 \\
\hline 18 & 18 & 0 & 1 & 0 \\
\hline 19 & 8 & 12 & 13 & 3 \\
\hline 20 & 12 & 11 & 6 & 3 \\
\hline 21 & 18 & 0 & 1 & 0 \\
\hline $\begin{array}{l}\text { Average } \\
\text { connectivity } \\
\text { weight ratio }\end{array}$ & 7/71 & 3.90 & - & - \\
\hline
\end{tabular}

As Table 3 shows, to avoid influence on the image of banks, the authors decided to impersonate the data by replacing the bank names with serial numbers. Table 3 confirms that the banks had different quantitative levels of available relationships; the average connectivity weight of banks was 7.71 in the set with direct links and 3.90 in that with inverse links. The average connectivity weight ratio of financial institutions indicates the average number of other financial institutions with a link in performance across a large number of financial institutions. That is, on average, each bank has a direct correlation with eight other banks and an inverse correlation with four other banks.

Based on the binary matrices of the financial institutions' interconnections, the graphs of the relationships for the banks have been constructed (Figure 1).

As Figure 1 shows, the graph is undirected, that is, its edges are not assigned a direction. According to the resulting graph of relations for banks, it is concluded that banks 1, 2, 4, 7-13, 16, and 19 have a large number of relations with others (graphical form allows seeing clearly all available links). It means that these banks may have joint clients.

Meanwhile, banks 5, 14, 18, and 2 have no links with other analyzed banks, and bank 15 has a direct correlation with bank 13 only, so it could be partnership.

The next step is establishing the trajectory from one vertex to another in the graph according to the existing algorithms (Cristofides, 1978) (Figure 2).

According to Figure 2, the obtained graph may contain some directions of achievement, as shown from top 1 to top 7. That is, considering banks as tops, one can assume a hidden link among banks $1,2,4$, and 7 . That is, bank 1 correlates with bank 7 through banks 2 and 4 .

The next step is the graph transformation from non-oriented to oriented (Figure 3 ).

As Figure 3 shows, constructing an oriented graph makes it possible to identify and clearly demonstrate all possible directions of relations between the investigated financial institutions (banks). All 


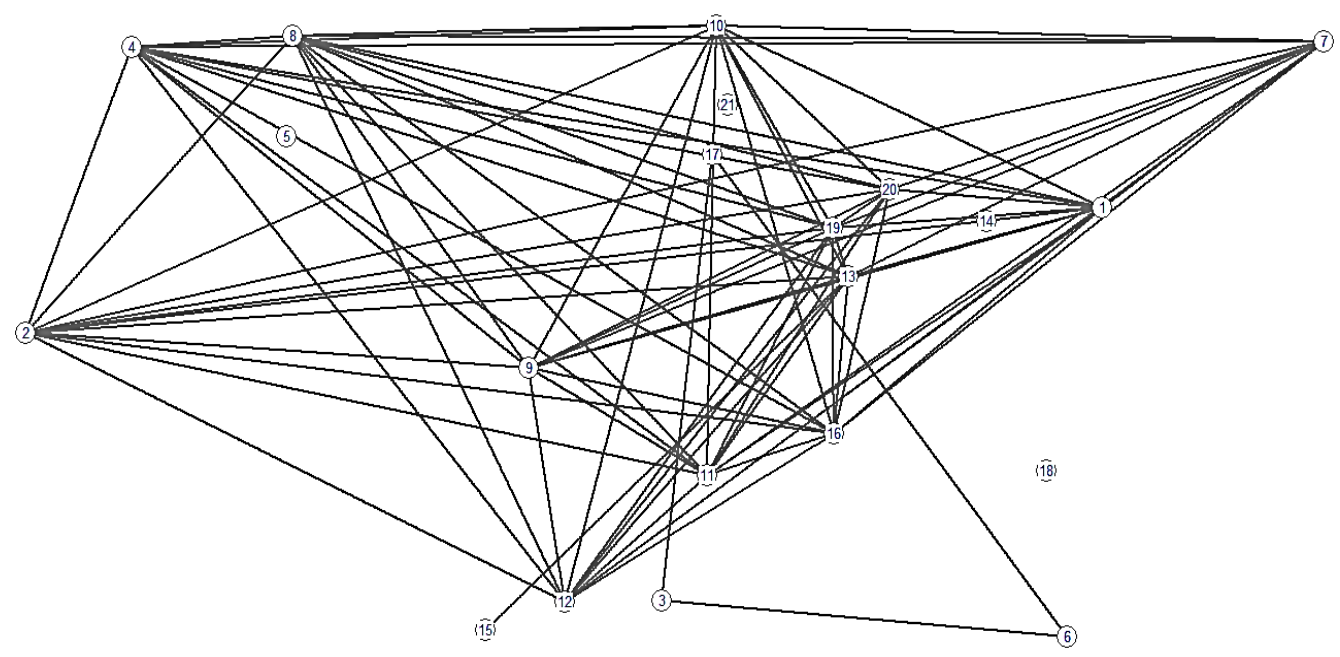

Figure 1. General view of the undirected link graph for banks with direct links

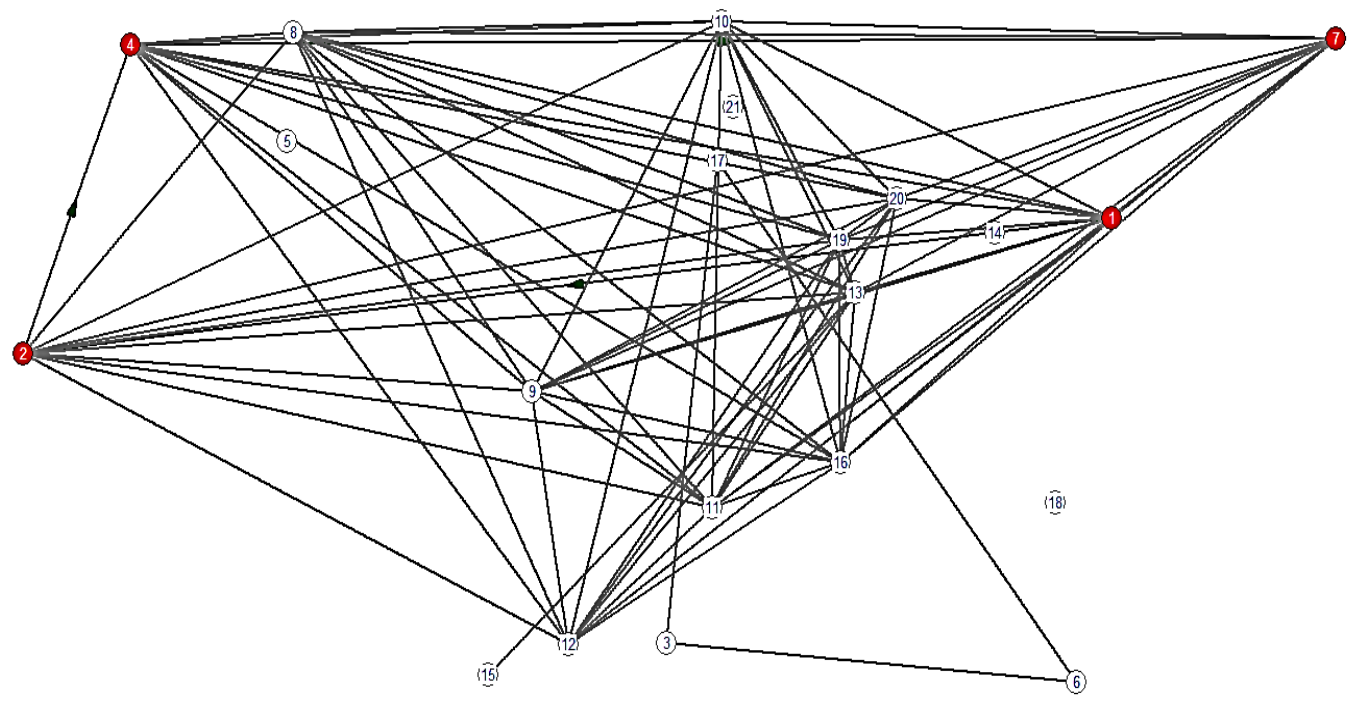

Figure 2. Selecting the trajectory (an example) from top 1 to top 7

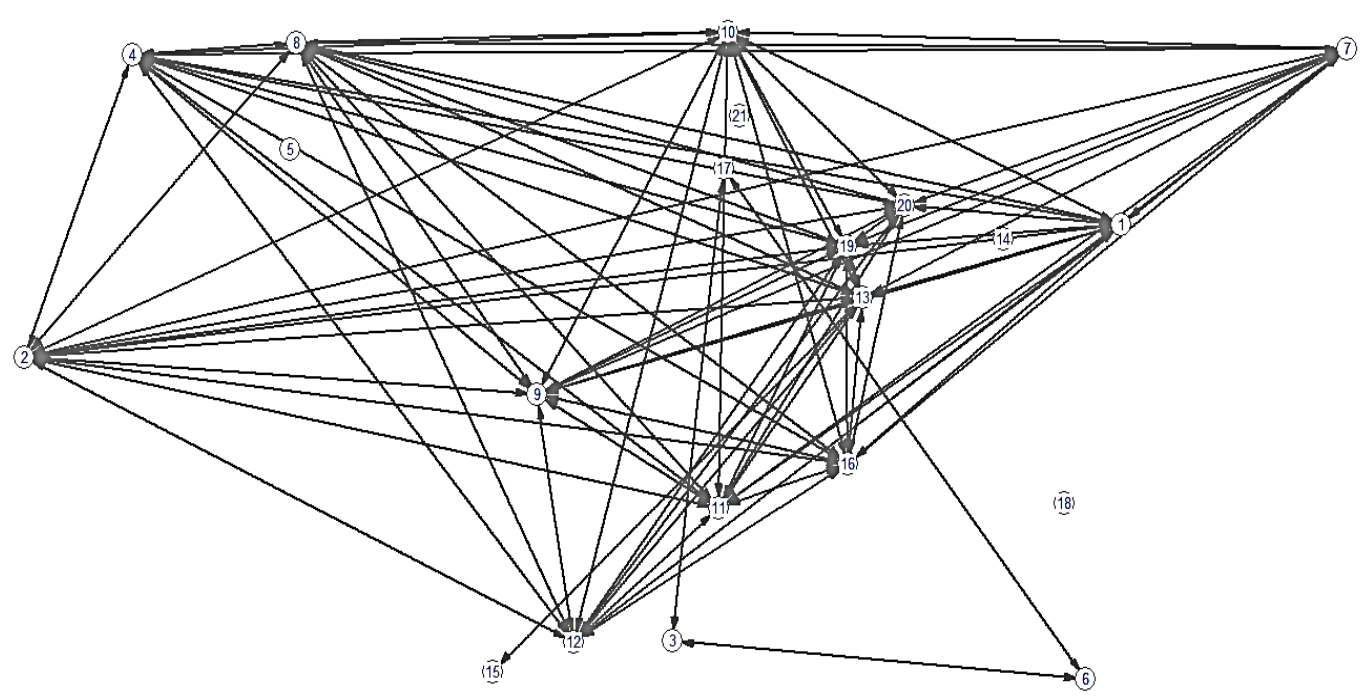

Figure 3. General view of the oriented link graph for banks with direct links 


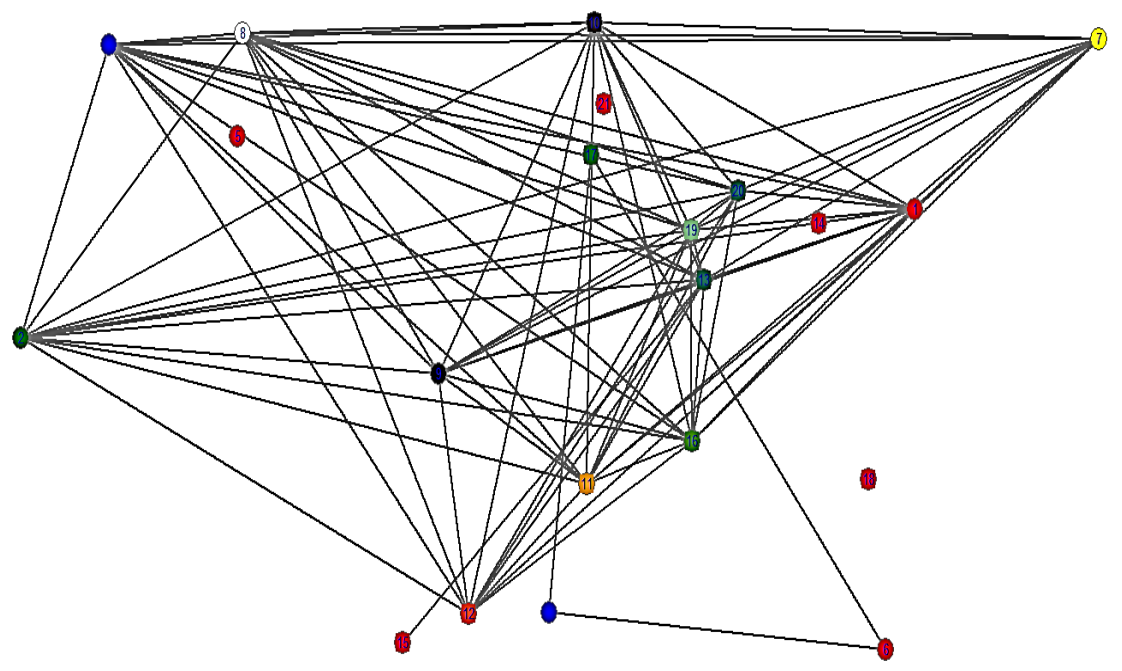

Figure 4. Selecting contours or cycles that can be created by banks

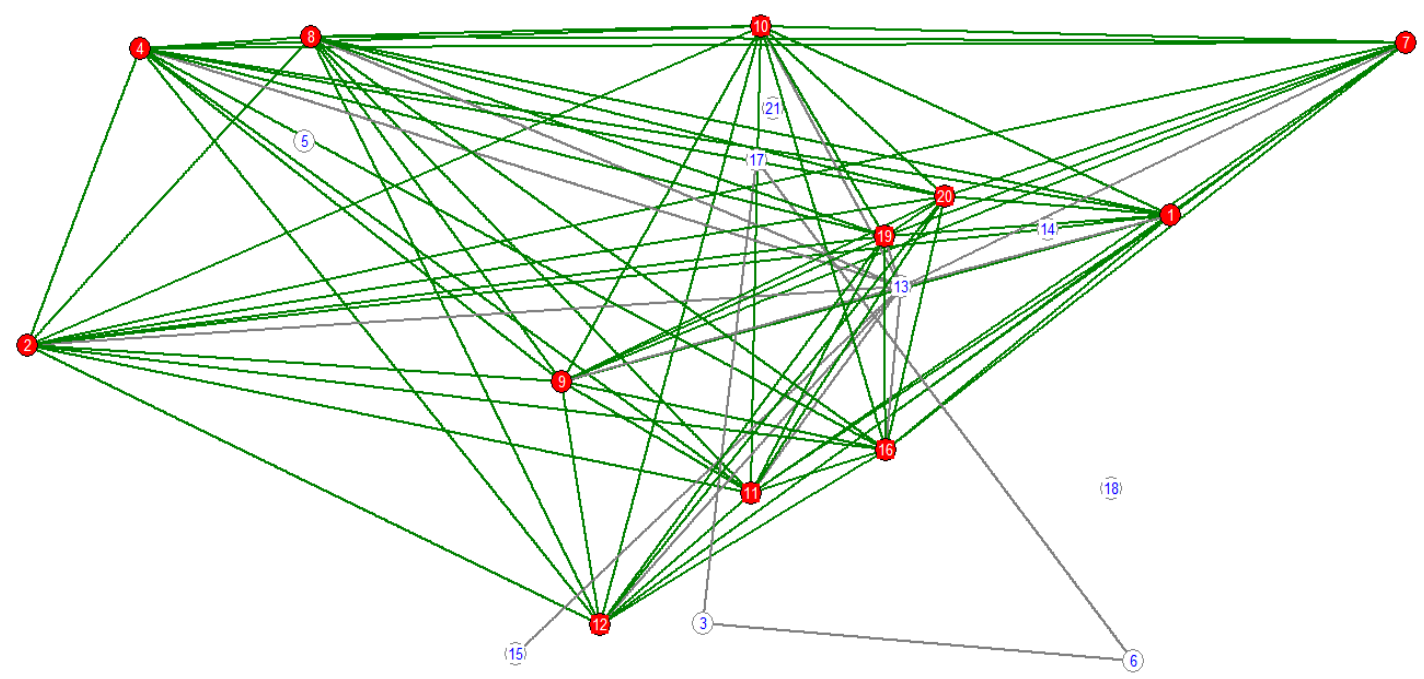

Figure 5. Finding the maximum clique in the graph (an example)

of them are subject to further review to determine the risk of money laundering, terrorist financing and financing the proliferation of mass destruction weapons.

The chromatic number of the graph (Cristofides, 1978) (Figure 4), which is 17 in this case, is then calculated. This number determines the least number of colors necessary to correctly color the graph so that the ends (vertices) of any edge have different colors. This number also determines the number of independent subsets (according to the number of colors).

In this case, the interpretation of the bank may indicate that in the banking market under study, there is a sufficient number (17) of interconnected banks, but established by different beneficiaries of financial institutions in the banking market under study.

The following step is calculating all cliques in the graph. A clique in an undirected graph is such a subset of its vertices where every two vertices are joined by an edge. Also, cliques can identify banks that have any relationships or links. The clique is also a complete subgraph, and the maximum clique is a chain of 20-1916-12-11-10-9-8-7-4-1-1; that is, it is not contained in any other clique (Figure 5). Figure 5 shows that the largest conglomerate of multiple financial institutions contains 12 (clique num- 
Table 4. Summary of bank connectivity data obtained

\begin{tabular}{l|c|c}
\hline \multicolumn{1}{c|}{ A set of financial institutions (banks) } & Connectivity level, \% & Non-connectivity level, \% \\
\hline Banks of foreign banking groups with direct links & 41.50 & 58.50 \\
\hline Banks of foreign banking groups with inverse links & 23.26 & 76.64 \\
\hline
\end{tabular}

ber) ones. The total number of cliques received in the graph confirms the links between banks, which can be used to further validate them to identify networks through connectivity. It can also be noted that the resulting graph is perfect because its chromatic number equals the clique number (Cristofides, 1978).

\subsection{Final analysis}

The final step in determining the connectivity level of banks is to conduct a final analysis of the data obtained to confirm the hypotheses on the pres- ence of connectivity between financial institutions. Table 4 gives the results of calculating bank connectivity ratios.

Thus, it is found that the number of unrelated banks exceeds the number of related ones. This may indicate that there are hidden links between them. Therefore, it is desirable to improve measures to assess money laundering risk for those banks that enter into affiliated financial institutions, so they can create networks that provide the basis for possible money laundering and terrorist financing.

\section{CONCLUSION}

Applying the FATF international financial monitoring standards to primary financial monitoring entities, i.e., banks, aims at using a risk-oriented approach that takes into account the relationships between them, that is, possible use of networks. To identify entities (financial institutions) with common economic risk, the need to determine the level of correlation between them is justified by the example of foreign-owned banking institutions. Based on the selected profitability criterion, the connectivity and non-connectivity levels of this group of banks were calculated, which showed that the number of unconnected banks exceeds the number of connected ones. This can be effectively confirmed, because the country of origin of the bank's foreign capital is different, which significantly influences the strategy of the bank's business and its corporate culture. The level of differences in financial activity may be significant; therefore, the ability to create a network, in particular in terms of the potential for money laundering, will be limited.

Each surveyed bank has a different linkage ratio, both direct and inverse, from 0 to 13 , but on average it has a direct link with eight other banks and an inverse link with four other banks. When considering banks as the graph tops, the assumption is made of a hidden link between some banks, which can only be achieved by using this method of analysis. It allows calculating all existing links between the investigated banks to check them carefully for risk assessment. Translating the non-oriented graph into oriented has made it possible to identify and demonstrate possible directions of network connections between the banks, which may be further analyzed to determine the risk of money laundering, terrorist financing, etc.

The proposed toolkit will improve the assessment of the risk of involvement in the possible money laundering in the financial services market, highlight many independent banks, prove the impact of one bank on another; this will help prevent the risk influence of affiliated financial institutions on the ability to create networks for laundering. It will also enhance the effectiveness of control over financial transactions that are subject to both mandatory and internal financial monitoring.

The advantages of the proposed approach are as follows: the use of the annual financial statements published by banks according to the NBU requirements; comprehensive assessment of the connectivity level 
of financial institutions based on easy-to-use quantitative indicators; the possibility of moving from a quantitative value of the connectivity level assessment to a qualitative interpretation of the risk of possible money laundering. The use of graph theory as network theory is a promising direction for developing approaches to the further implementation and improvement of measures aimed at preventing and combating money laundering and terrorist financing.

\section{ACKNOWLEDGMENT}

The article is prepared based on the results of the fundamental fiscal theme No. 54/2018-2020 "Riskoriented approach in resisting money laundering, terrorist financing and proliferation of mass destruction weapons".

\section{REFERENCES}

1. Achkasova, S. (2019). The Scale Measurement of the Indicators of the Stress Resistance Assessment of Insurance Companies in Ukraine. Economic Studies, 2, 161-183. Retrived from https:// ideas.repec.org/a/bas/econst/ y2019i2p161-183.html

2. Avramchykova, N. T. (2012). Teoretycheskiie aspekty otsenky kachestva ekonomicheskogo prostranstva [Theoretical aspects of assessing the quality of the economic space]. Regionalnaya ekonomika: teoriya i praktika Regional economics: theory and practice, 35, 213. (In Russian). Retrieved from https://cyberleninka.ru/article/n/teoreticheskieaspekty-otsenki-kachestva-ekonomicheskogo-prostranstva

3. Batrakova, L. H. (2005). Ekonomycheskiy analiz deyatelnosti komercheskogo banka [Economic analysis of commercial bank activity] (368 p.) Moscow: Logos. (In Russian). Retrieved from https:// www.twirpx.com/file/16220/

4. Buriak, A. (2010). Ekonomichnyi analiz v diialnosti bankivskykh ustanov [Economic analysis of banking institutions]. Ekonomicnyi analiz - Economic analysis, 10, 133-136. (In Ukrainian) Retrieved from https://econa.at.ua/Vypusk_7/buryak.pdf

5. Chepyk, A. E. (2013). Issledovanye svoisvoystv ekonomicheskogo prostranstva regiona s pomoshchyu statisticheskikh metodov
[The study of the properties of the economic space of the region using statistical methods]. Regionalnaya ekonomika, 24, 127132. (In Russian). Retrieved from https://cyberleninka.ru/article/n/ issledovanie-svoystv-ekonomicheskogo-prostranstva-regionas-pomoschyu-statisticheskihmetodov

6. Cristofides, N. (1978). Teoriya grafov. Algoritmicheskiy podkhod [Graph theory. Algorithmic approach] (432 p.). Moscow: Mir. (In Russian). Retrieved from https:// www.twirpx.com/file/47256/

7. FATF. (2012). Mizhnarodni standarty z protydii vidmyvanniu dokhodiv ta finansuvanniu teroryzmu i rozpovsiudzhenniu zbroi masovoho znyshchennia [International standards for combating money laundering and terrorist financing and the proliferation of weapons of mass destruction]. (In Ukrainian). Retrieved from http:// www.sdfm.gov.ua/content/file/ Site_docs/2012/22.03.2012/1.pdf

8. Fedotova, K. O. (2010). Umovy vynyknennia dyvidendnoi premii pry rozmishchenni aktsii na fondovomu rynku [Conditions for the occurrence of a dividend premium when placing shares on the stock market]. Bulletin of the Khmelnytsky National University, 6(4), 25-35. (In Ukrainian). Retrieved from http://irbis-nbuv. gov.ua/cgi-bin/opac/search. exe?S21CNR=20\&S21STN=1\&S21 $\mathrm{REF}=2 \& \mathrm{C} 21 \mathrm{COM}=\mathrm{S} \& \mathrm{I} 21 \mathrm{DBN}=\mathrm{R}$
$\mathrm{EF} \& \mathrm{P} 21 \mathrm{DBN}=\mathrm{REF} \& \mathrm{~S} 21 \mathrm{All}=\% 3 \mathrm{C}$. \%3EID\%3DREF-0000215442\%3C. \%3E\&\&S21FMT=ASP_meta

9. Gerasimovich, A. M., Alekseenko, M. D., \& Parasiy-Verhunenko, I. M. (2004). Analiz bankivskoi diialnosti-Analysis of banking activity (599 p.). Kyiv: KNUE. (In Ukrainian). Retrieved from http:// studentbooks.com.ua/content/ view/116/54/

10. Teorija grafiv [Graph theory]. (n.d.). Retrieved from https:// www.academia.edu/25704406/\%D 0\%A2\%D0\%B5\%D0\%BE\%D1\%8 0\%D1\%96\%D1\%8F_\%D0\%B3\%D 1\%80\%D0\%B0\%D1\%84\%D1\%96 \%D0\%B2

11. Hlibko, S. V., Vnukova, N. M, Hontar, D. D., Anisimova, H. V., \& Liubchych, A. N. (2019). Risk-Oriented Approach to Determining Bank's Capital Size according to Requirements of Basel Committee on Banking Supervision. Economic Studies, 1, 56-71. Retrieved from https://ideas.repec.org/a/bas/ econst/y2019i1p56-71.html

12. Hnatyshak, O. (2011). Teoretykometodychni zasady formuvannia vartosti banku [Theoretical and methodological bases for creating bank value]. Economic analysis, 9(2), 99-102.

13. Kavun, S. V., Mykhalchuk, I. V., Kalashnykova, N. I., \& Zyma, O. G. (2012). A Method of InternetAnalysis by the Tools of Graph Theory. In J. Watada, T. Watanabe, G. Phillips-Wren, R. Howlett, \& 
L. Jain (Eds.), Intelligent Decision Technologies. Smart Innovation, Systems and Technologies (pp. 3544), Vol. 15, Part 1. Berlin: Springer. http://dx.doi.org/10.1007/9783-642-29977-3_4

14. Kavun, S., \& Vorotintcev, M. (2016). Credit Risk Assessment of Financial Institutions Activity. Journal of Finance and Economics, 4(5), 142-150. http://dx.doi. org/10.12691/jfe-4-5-3

15. Khrystenko, M. (2012). Vartisnooriientovane upravlinnia bankom: zarubizhnyi dosvid [Cost-oriented banking management: international experience]. Bulletin of the $N B U, 11,59-65$. (In Ukrainian). Retrieved from http://nbuv.gov.ua/ UJRN/Vnbu_2012_11_22

16. Kochetkov, V. N. (1999). Analiz bankovskoy deyatelnosti: teoretikoprikladnoy aspect [Analysis of banking activity: theoretical and applied aspect] (190 p.). Kyiv: IAPM. (In Russian). Retrieved from https://www.twirpx.com/ file/774928/

17. Kofman, A. (1968). Setevyye metody planirovaniya $i$ ikh primeneniye [Network planning methods and their application] (180 p.) Moscow. (In Russian). Retrieved from https://www.twirpx.com/ file/203966/

18. Kohdenko, V. G. (2012). Razrabotka systemy kontrolia za effektivnostiu upravleniya stoymostiu kompanii [Development of a system for monitoring the effectiveness of company value management]. Finance and Credit, 8, 2-10. (In Russian).

19. Ministry of Finance of Ukraine. (2012). Mizhnarodnyi standart bukhhalterskoho obliku 24 "Rozkryttia informatsii pro zviazani osoby": Standart IASB vid 01.0.2012 r. [International Accounting Standard 24 Related Party Disclosures: IASB Standard dated January 1, 2012]. Retrieved from http://zakon3.rada.gov.ua/laws/ show/929 043

20. Ministry of Finance of Ukraine. (2012). Pro zatverdzhennia Polozhennia (standartu) bukhhalterskoho obliku 23 "Rozkryttia informatsii shchodo poviazanykh osib" [On Approval of Accounting Regulations (Standard) 23 "Related Party Disclosures"]. Retrieved from http://zakon3.rada.gov.ua/ laws/show/z0539-01

21. Ministry of Finance of Ukraine. (2016). Pro zatverdzhennia Kryteriiv ryzyku lehalizatsii (vidmyvannia) dokhodiv, oderzhanykh zlochynnym shliakhom, finansuvannia teroryzmu ta finansuvannia rozpovsiudzhennia zbroi masovoho znyshchennia: Nakaz vid 08.07.2016 № 584 [On approval of the Criteria for risk of legalization (laundering) of proceeds from crime, terrorist financing and financing of the proliferation of mass destruction weapons: Order No. 584 as from July 8, 2016]. Retrieved from https://zakon.rada. gov.ua/laws/show/z1047-16

22. Moroz, M., Savluk, M., \& Pukhovkina, M. (2000). Bankivski operatsii [Banking operations] (384 p.). Kyiv: KNUE. (In Ukrainian). Retrieved from https://www. twirpx.com/file/302836/

23. National Bank of Ukraine. (2001). Pro zatverdzhennia Instruktsii proporiadok rehuliuvannia diialnosti bankiv v Ukraini: Postanova Pravlinnia Natsionalnoho banku Ukrainy vid 28.08.2001 r. № 368 (zi zminamy ta dopovnenniamy) [On approval of the Instruction on the procedure for regulating the activity of banks in Ukraine: Resolution of the Board of the National Bank of Ukraine dated August 28, 2001 No. 368 (as amended)]. Retrieved from http://zakon.rada. gov.ua/laws/show/z0841-01

24. National Bank of Ukraine. (2016). Pro zatverdzhennia Polozhennia pro vyznachennia bankamy Ukrainy rozmiru kredytnoho ryzyku zaaktyvnymy bankivskymy operatsiiamy: Postanova Pravlinnia Natsionalnoho banku Ukrainy vid 30.06.2016 r. № 351 [On approval of the Regulation on determining the size of credit risk by active banking transactions by banks of Ukraine: Resolution of the Board of the National Bank of Ukraine dated June 30, 2016 No. 351]. Retrieved from www.bank.gov.ua/document/ download? docId $=33378802$
25. National Bank of Ukraine. (2019a). Natsionalnyi bank Ukrainy zalyshyv bez zmin kryterii rozpodilu bankiv na hrupy na 2019 rik [The National Bank has unchanged the criteria for allocating banks to groups by 2019]. Retrieved from https://bank.gov.ua/ control/uk/publish/article?art_ id $=89250434 \&$ cat $\_$id $=55838$

26. National Bank of Ukraine. (2019b). Ohliad bankivskoho sektoru za traven 2019 roku [Banking Sector Review for May 2019]. Retrieved from https://bank.gov. ua/news/all/oglyad-bankivskogosektoru-traven-2019-roku

27. National Bank of Ukraine. (n. d.) Official website. Retrieved from https://www.bank.gov.ua

28. Omelchenko, O., Dorokhov, O., Kolodiziev, O., \& Dorokhova, L. (2018). Fuzzy Modeling of Creditworthiness Assessments of Bank's Potential Borrowers in Ukraine. Economic Studies, 27(4), 100-125. Retrieved from https://www.researchgate.net/ publication/328824996_Fuzzy_ modeling_of_the_creditworthiness_assessments_of_bank's_potential_borrowers_in_Ukraine

29. Poliakova, A. H., \& Simarova, I. S. (2014). Kontseptualnaia model upravleniya razvitiiem regiona s uchetom urovnia prostranstvennoi sviaznosty [Conceptual model for managing the development of a region taking into account the level of spatial connectivity]. Economika regiona - Regional economy, 2, 3242. (In Russian). Retrieved from https://cyberleninka.ru/article/n/ kontseptualnaya-model-upravleniya-razvitiem-regiona-s-uchetom-urovnya-prostranstvennoysvyazannosti

30. Prymostka, L. O. (1999). Finansovyi menedzhment banku [Financial management of the bank] (280 p.). Kyiv: KNUE. (In Ukrainian). Retrieved from http://fingal. com.ua/content/view/225/54/

31. Rose, P. S., \& Kolari, J. W. (1995). Financial institutions: understanding and managing financial services. Retrieved from http:// onscene.ru/Financial-institutions- 
-understanding-and-managingfinancial-services-Peter-S-RoseJames-W-Kolari/2/bhgbjdd

32. Shkala Cheddoka [Chaddock's scale]. Retrieved from http://math. semestr.ru/corel/cheddok.php

33. The State Financial Monitoring Service of Ukraine (SFMS). (2016). Zvit pro provedennia natsionalnoi otsinky ryzykiv u sferi zapobihannia ta protydii lehalizatsii (vidmyvanniu) dokhodiv, oderzhanykh zlochynnym shliakhom, ta finansuvanniu teroryzmu [Report on conducting a national risk assessment in the field of prevention and counteraction to the legalization (laundering) of proceeds of crime and terrorism financing]. (In Ukrainian). Retrieved from http://www.sdfm.gov.ua/content/ file/Site_docs/2016/20161125/ zvit_ukr.pdf

34. The State Financial Monitoring Service of Ukraine (SFMS). (2018). Posibnyk shchodo zastosuvannia pidkhodu, shcho gruntuietsia na otsintsi ryzyku vidmyvannia koshtiv ta finansuvannia teroryzmu [Guide on the application of a risk-based approach to the assessment of money laundering and terrorist financing]. (In Ukrainian). Retrieved from http://www.sdfm.gov.ua/content/file/Site_docs/2018/20180620/ Zmist.pdf

35. The Verkhovna Rada of Ukraine. (2010). Podatkovyi kodeks Ukrainy vid 02.12.2010 r. №2755-VI (zizminamy ta dopovnenniamy) [Tax Code of Ukraine dated December 2, 2010 No. 2755-VI (as amended)]. Retrieved from http://zakon5.rada.gov.ua/laws/ show/2755-17

36. The Verkhovna Rada of Ukraine. (2019). Pro zapobihannia ta protidiiu legalizatsii (vidmyvanniu) dohodiv, oderzhanykh zlochynnym shliakhom, finansuvanniu teroryzmu ta finansuvanniu rozpovsiudzhennia zbroi masovoho znyshchennia: Proekt Zakonu Ukrainy vid 01.11.2019 [On Preventing and Counteracting to Legalization (Laundering) of the Proceeds of Crime, Terrorist Financing and Financing Proliferation of Weapons of Mass Destruction]. Retrieved from http://w1.c1.rada.gov.ua/pls/ zweb2/webproc4_1?pf3511=66949

37. Trydid, O., Kavun, S., \& Goykhman, M. (2014). Synthesis concept of information and analytical support for bank security system. Actual Problems of Economics, 11(161), 449-461. Retrieved from https://www.researchgate.net/ publication/273002420_Synthesis_concept_of_information_ and_analytical_support_for_bank_ security_system

38. Vnukova, N, Hontar D., \& Vorotyntsev M. (2018). Money laundering risk management tools based on determining the level of co-ordination of financial companies and credit unions. Development Management, 4(4), 40-51. http://dx.doi.org/10.21511/ dm.4(4).2018.04 